\title{
Experience and enlightenment: "Customer-oriented" nine-stage major gifts management model of world-class U.S. universities
}

\author{
Chenghua Lin, Yanjie Xie, and Ruixue $\mathrm{Xu}^{*}$
}

doi: http://dx.doi.org/10.18543/tjhe-7(1)-2019pp33-65

Received: 8 April 2019

Accepted: 5 November 2019

\begin{abstract}
Since the 1990s, "customer orientation" marketing has been widely applied to major gifts management of world-class U.S. universities, forming a donorcentered model for major gifts management. It focuses on donor demands management, relationship cultivation and value creation, which has a major effect on university fundraising and development. Through literature review and case study of the University of Pittsburgh, this study analyzes the major gifts management model of world-class U.S. universities in terms of theory, structure, operation model, and development characteristics. The findings show that there are two important characteristics of the organizational structure of major gifts management in the United States: one is the donation market segmentation and the donor classification management; the other is the refinement of donation management functions. And this paper proposes a nine-stage major gifts management model of world-class U.S. universities, which contains "Definition-Identification- Qualification-Development of Strategy-Cultivation-Solicitation-Negotiation-Acknowledgment -Stewardship." Finally, this paper summarizes the development trend of major gifts management: emphasizing donor's value creation, donor internalization and capitalization, cultivating prospective donors from national to international, moving towards integration of leading capacity building and donor orientation.
\end{abstract}

* Chenghua Lin (chlin@zju.edu.cn) is Associate Professor and Deputy Director of Institute of Technology Innovation and Management, Research Institute of China's Science, Technology and Education Policy, School of Public Affairs, Zhejiang University, China.

* Yanjie Xie (xieyanjie94@163.com) is a PhD student in School of Public Affairs in Zhejiang University, China.

* Ruixue Xu (954015186@qq.com) is a Master's student in School of Public Affairs in Zhejiang University, China.

More information about the authors is available at the end of this article.

Fund information: National (China) Education Science Planning Ministry of Education Key Research, Capital Campaign and Its Implications for Double-Class Construction, Project Number: DIA160332. 
Keywords: major gifts; customer orientation; demand management; value creation; management model.

\section{Introduction}

The term "Major gifts" refers to a relatively large sum of single donation received by a non-profit organization which is usually paid in the form of installments. ${ }^{1}$ Major gifts are powerful tools for universities to cope with social changes and competition in higher education, alleviate financial constraints and fulfill their mission. Therefore, access to social donations is increasingly valued by universities. In recent years, major gifts in the higher education sector have been setting new world records. In October 2018, the Guangdong Guoqiang Public Welfare Foundation in China made the claim that it would donate 2.2 billion yuan to Tsinghua University in the next 10 years to support the basic research and frontier science, talent training, and high-end talents introduction to promote its development. According to public records, this is the largest single donation ever received by Chinese universities. ${ }^{2}$ In November 2018, Michael Bloomberg, the former mayor of New York City and founder and CEO of Bloomberg L.P., announced that he would donate $\$ 1.8$ billion to his alma mater, Johns Hopkins University, to help eligible low- and middle-income applicants and students, in the form of grants, to have equal access to quality educational resources. Up to 2013, Bloomberg has donated more than $\$ 1$ billion to Johns Hopkins University. ${ }^{3}$ Many factors are believed to facilitate major gifts development in higher education, including the introduction of corresponding tax relief policies and proportional donation schemes by the government, the increasing specialization of fundraising in universities, and the shift of donors' motivation from "naming" to "cooperation", meaning the new generation of donors prefer investing in a certain value and trying to find universities willing to cooperate by exploring their unique "advantages" and "ideas". Therefore, attracting major gifts more often than not tops the agenda of a university in terms of donation management. This paper intends to explore

${ }^{1}$ Kathleen S. Kelly, Effective Fund-raising Management (Mahwah: Routledge, 1998).

2 "Tsinghua won the highest donation amongst domestic universities for 2.2 billionyuan," [in Chinese] People, last modified October 23, 2018, http://edu.people.com.cn/ n1/2018/1023/c1053-30357207.html.

3 "Record! Bloomberg announced a donation of $\$ 1.8$ billion to his alma mater," [in Chinese] People, last modified November 19,2018, http://ah.people.com.cn/n2/2018/1119/ c358315-32305418.html. 
the possible management modes of major gifts of world-class U.S. universities and its enlightenment. To this end, this paper analyzes the mode of a major gift in American universities based on the "customer-oriented" theory, and explores several research topics that can be studied in the future. It will present the history and basic notions of customer-oriented theory, then describe the organizational structure of "customer-oriented" major gifts management and identify the characteristics of "customer-oriented" major gifts management mode from nine steps. Finally, the issues that can be studied in the future will be discussed.

\section{Literature review}

University major gifts are generally related to the significant large-scale development plans or projects, whose core being the relationship between universities and donors. ${ }^{4}$ Under certain strategic frameworks, such as identification, cultivation, solicitation, and stewardship of major gifts donors, the demand matching and value creation between universities and donors can be achieved so that donors would donate the maximum amount they can afford. ${ }^{5}$ American higher education has a valuable tradition for individuals and society to donate to higher education. The promotion, raising, and management of donations in American universities have entered specialization stage, forming an advanced professional management and fundraising mechanism. ${ }^{6}$ In Europe, reports of a decline in the number of donors in some of the more developed fundraising markets (including Germany, France, Italy and the UK), suggest that future giving levels may indeed be increasingly dependent on higher value donors. This places greater emphasis on the importance of successfully engaging philanthropists; both potential legators and major donors. ${ }^{7}$ Major gifts procuring is a low cost and high-performance fundraising method favored and valued by universities, as it is believed to be of great importance for their sustainable development. Firstly, major gifts are the main

${ }^{4}$ Kathleen S. Kelly and Chuck Kelly, Fund raising and public relations: A critical analysis (Hillsdale: Lawrence Erlbaum Associates, 1991).

${ }_{5}$ Michael J. Worth, New Strategies for Educational Fund Raising (Westport: Rowman \& Littlefield Publishers, 2002).

6 Yan Meng, Chengwen Hong, Strategies and implications of fund-raising campaign at the University of Toronto," Chongqing higher education research, no.5 (2017): 92-100.

7 "Special Focus: What today's philanthropists really want," European Fundraising Association, last modified September 18, 2019, https://efa-net.eu/features/special-focus-whattodays-philanthropists-really-want. 
contribution to donation funds, reflecting the " $1 / 9$ " principle of university fund-raising, i.e. $10 \%$ of donors contributing $90 \%$ of the donations. Secondly, major gifts set a "benchmark effect" on donors' behavior. In other words, major gifts donors tend to establish a donor "benchmark" image, thus encouraging other donors to increase donation frequency and amount. Thirdly, major gifts generate the "marginal revenue increase effect" of university brands. That is, it promotes the university's reputation and enhances its brand value. For example, the most authoritative world university ranking-US News and World Report regards the source of school funding and the alumni donation as important indicators for measuring the quality of universities.

Research on factors affecting donation based on the university's own perspective is relatively fruitful, such as the Vice President of the University of Bristol, Eric Thomas's research found that university leaders, off-campus leaders, and professional development offices are the three basic elements of a successful fundraising in a university. He pointed out that the effective operation of the development office requires three core conditions: development plan, alumni relationship and fundraising management. ${ }^{8} \mathrm{~A}$ study by William found that attractive donations and targeted alumni based on personality traits are important factors influencing the ongoing donation. ${ }^{9}$ A study of 10 different types of higher education institutions by Bruce and Margaret found that different types of higher education institutions have very different definitions of fundraising and fundraising utility. ${ }^{10}$ They believe that there is no one-size-fits-all fundraising model. Successful fundraising projects are often associated with university leadership support, fundraising reasons and commitments, leadership of the chief development officer, and corporate operations. ${ }^{11}$ There are also some factors from donor side, such as perceived donation efficacy (PDE), which is defined as the degree to which donors believe their contributions will make a difference to the cause they are supporting, ${ }^{12}$ is a kind of beliefs reflects that a behavior will result in certain

8 Thomas, E., Blair, M.K., Hughes-Hallett, T. y Lampl, P, Increasing voluntary giving to higher education: Task Force report to Government. (Nottingham: Department for Education and Skills, 2004).

9 Yurong He, "A literature review of higher education donation system in China," China Electric Power Education, no. 28 (2011): 19-21.

${ }^{10}$ Margaret A. Duronio and Bruce A. Loessin, Effective Fund Raising in Higher Education: Ten Success Stories (San Francisco: ERIC, 1991).

${ }_{11}$ Margaret A. Duronio and Bruce A. Loessin, Effective Fund Raising in Higher Education: Ten Success Stories (San Francisco: ERIC, 1991).

${ }^{12}$ René Bekkers and Pamala Wiepking, "A Literature Review of Empirical Studies of Philanthropy: Eight Mechanisms That Drive Charitable Giving," Nonprofit and Voluntary Sector Quarterly 40, no. 5 (2011): 924-973. 
outcomes. ${ }^{13}$ While self-efficacy reflects one's beliefs about his/her ability to perform a behavior. ${ }^{14}$ Apart from this, organizational credibility, as a global evaluation of an organization's capability to uphold its promises, has been shown to influence donation amounts but not donation choice, ${ }^{15}$ and organizational credibility is less actionable for it can take significant time to meaningfully establish or change. ${ }^{16}$

Moves management is a term used primarily with the non-profit sector in relationship to donor development, and it is developed by David R. Dunlop, the Cornell University fundraiser, defined it as, "changing people's attitudes so they want to give." In other words, it is a way to manage the somewhat fuzzy process of taking a prospective donor down the path of productive cultivation activities. "Moves" are the actions an organization takes to bring in donors, establish relationships, and renew contributions. ${ }^{17}$ Therefore, each move is a cultivation activity that penetrates your donor's busy mind. A successful moves management model, at its core, takes specific, targeted, quantifiable efforts and actions to shift influential donors or members from a passive or one-time contribution to an active, ongoing relationship with the organization that takes place through multiple channels and feedback opportunities. In practice, some scholars and practitioners would think of moves management as a series of milestones that lead to a gift, often through a four-step process which contains dentification, cultivation, solicitation and stewardship ${ }^{18}$ or five-step process which contains identification, qualification, cultivation, solicitation and stewardship..$^{19}$ In the meantime, there are some other versions of moves management. Such as rate the prospects; separate all

${ }^{13}$ Ronald W. Rogers, "A Protection Motivation Theory of Fear Appeals and Attitude Change 1," The Journal of Psychology 91, no. 1 (1975): 93-114.

${ }_{14}$ Albert Bandura, "The Explanatory and Predictive Scope of Self-Efficacy Theory," Journal of Social and Clinical Psychology 4, no. 3 (1986): 359-373.

15 Tatiana M. Fajardo, Claudia Townsend, and Willy Bolander, "Toward an Optimal Donation Solicitation: Evidence from the Field of the Differential Influence of Donor-Related and Organization-Related Information on Donation Choice and Amount," Journal of Marketing 82, no. 2 (2018): 142-152.

${ }^{16}$ Ryall Carroll and Luke Kachersky, "Service Fundraising and the Role of Perceived Donation Efficacy in Individual Charitable Giving," Journal of Business Research 99 (2019): 254-263.

17 "The New Model of Moves Management For Effective Fundraising”, Avectra, accessed October 5, 2019, http://cdn2 hubspot.net/hub/447141/file-2184258567-pdf/The-New-Model-OfMoves-Management-For-Effective-Fundraising_Avectra.pdf?t=1417809451029.

18 "Donor Cultivation Is Key to Success," Duke Haddad, last modified June 29, 2018, https://www.nonprofitpro.com/post/donor-cultivation-is-key-to-success/.

19 “Fundraising Cycle," Funds101, last modified January 30, 2013, http://funds101. blogspot.com/2013/01/fundraising-cycle.html. 
the prospects based on their possibility to make a gift; set priorities and plan for each category; create cultivation moves; review and reorganize the list. ${ }^{20}$ In her book, Donor-Centered Fundraising, author Penelope Burk points out that "donors are people too." 21 That is, fundraising is not just a numbers game. It is about engaging donors in a two-way dialogue that goes far beyond the traditional transactional approach of simply asking for annual contributions.

\section{Theoretical background}

In the long-term university fundraising practice and related research, the United States has formed a relatively rich fundraising theories. Daniel L. Conrad also put forward the theory of Transaction Analysis. According to the theory, public donation is a kind of basic value exchange situations. University fundraising is a basic value transaction between university and donors under the principle of mutual benefit and win-win cooperation. The University fulfills its mission, improves its conditions and achieves its goal by collecting social donations. At the same time, donors realize their philanthropic ideals and meet their personal wishes and psychological needs through donation, including improving their self-image, social status, participating in social interaction, contributing altruism, and realizing their life value. In order to recognize the donor's philanthropic ideal and value pursuit, the university fundraising organization can take several means to meet the donor's donation needs and improve the donor's donation experience, depending on the donor's donation level and contribution. For example, name the school venue or donation fund project with the name designated by the donor or the donor or invite the donor to participate in various campus cultural activities by publicly thanking, etc. ${ }^{22}$ The transaction analysis theory expounds the value exchange between the two parties in the fundraising process, and provides important theoretical guidance for the university to carry out donor demand management, fundraising project design and donor policy evaluation. Apart from this, the literature using the Dictator Game from economic theory neglects to recognize fund raising is a complex and creative activity, and

20 "Major Gifts Series \#8: How to Use Moves Management To Raise Major Gifts This Year," Gailperry Association, https://www.gailperry.com/how-to-use-moves-management-toraise-major-gifts/.

${ }^{21}$ Michael J. Rosen, Donor-Centered Planned Gift Marketing (AFP Fund Development Series), vol. 192 (Hoboken: John Wiley \& Sons, 2010).

${ }_{22}$ Wei Tang, School management strategy: university budget allocation, fundraising and marketing (Taiwan: Wunan Book Publishing Co., Ltd, 2001). 
fundraising from the wealthy is fundamentally different from fundraising from the non-wealthy. ${ }^{23}$ The fundraising pyramid theory expounds the relationship between donor type, quantity and contribution rate of donors from the pyramid model of donor groups, and provides important theoretical support for the university's donor hierarchical management and donor relationship training. The fundraising time window theory expounds the important time nodes of the donation potential of donors from the time dimension, and provides theoretical guidance for the university to choose the best time for recruitment. Even though each of those theories could be applied to one aspect of fundraising management, but none could lead the whole process. Only customer orientation marketing theory could make it for it focus on recognizing the demands and meeting them, through which the non-material cost of donors could be reduced and the donation experience could be improved.

Customer orientation marketing theory was first proposed in 1960 by Theodore Levitt, Professor at Harvard Business School. He pointed out that many "product-oriented" businesses that were less concerned of customer demands would face the risk of market failure. If businesses wished to achieve sustainable development, they must focus on customer demands. ${ }^{24} \mathrm{In}$ 1990, Slater and Narver from Washington University emphasized that business focus should be placed on current and prospective customer demands. They also pointed out that by developing the relationship between corporations and customers, an accurate understanding of customer demands can be acquired. ${ }^{25}$ This point of view with high explanatory power was subsequently widely accepted and applied. Later, Kotler proposed the theory of "customer delivered value", pointing out that "customer delivered value" refers to the actual value that customers feel from the businesses, which marks the fundamental difference between total customer value and total customer cost. ${ }^{26}$ Total customer value refers to the benefits customers hope to attain by purchasing a certain product or service, including product value, service value, personal value and image value, while total customer cost refers to the time, effort, energy, and money spent by customers to purchase

${ }^{23}$ Jennifer A. Jones and David L. Daniel, "Academic and Practitioner Collaborations in Fundraising Research: A Case Study of One Action Research-Driven Collaboration," The Journal of Nonprofit Education and Leadership 9, no. 2 (2019).

${ }^{24}$ Theodore Levitt, Marketing Myopia (London: Boston, 1960).

${ }^{25}$ John C. Narver and Stanley F. Slater, "The Effect of a Market Orientation on Business Profitability," Journal of Marketing 54, no. 4 (1990): 20-35.

${ }^{26}$ Philip Kotler and Gary Armstrong. Fundamentos de Marketing, Google Scholar, accessed October 10, 2019, https://scholar.google.com/scholar?hl=en\&as_sdt=0\%2C5\&q=Ko tler\%2C+Philip\%2C+and+Gary+Armstrong.+Fundamentos+de+Marketing.+Pearson+Educac $\mathrm{i} \% \mathrm{C} 3 \% \mathrm{~B} 3 \mathrm{n} \% 2 \mathrm{C}+2003 . \& \mathrm{btnG}=$. 
a certain product, which includes monetary cost, time cost, psychic cost, and energy cost. When customers are purchasing a product, they often hope to minimize involved costs, but at the same time to receive more actual benefits, in order to maximize the satisfaction of their individual demands. Therefore, if a corporation wants to win the market competition and attract more prospective customers, they are supposed to provide products and services with more "customer delivered value" to their customers than their competitors. ${ }^{27}$

Sargeant puts forward the concept of "lifelong value" which measures the value of donors to a fund-raising organization throughout their lifetime. ${ }^{28}$ Through empirical research, he shows that cultivating donors' loyalty can save time and energy of fund-raising institutions. ${ }^{29}$ Apart from this, consumers' willingness to pay more or advocate depended on their belief that those actions would actually result in benefits for a distant party.$^{30}$ Since the 1990 s, with increasing competition for university fund-raising, customer orientation theory has been widely used in the management of university major gifts. It regards satisfying donor demands and increasing donor value as the core of major gifts management, paying special attention to the investigation of donor's financial capacity, preferences, motivation, and the analysis of donation market. The theory also focuses on the development of universitydonor relationship and the increase of "total customer value" with the attempt to lower the monetary and non-monetary costs of donation management through continuously optimizing university donation management strategy, process, project planning and human resource allocation, as well as increasing service quality and university's social influence.

\section{Objects and research methodology}

This paper seeks to answer the following research question: how do world-class U.S. universities manage their major gifts model and what is the

27 Philip Kotler and Gary Armstrong. Fundamentos de Marketing, Google Scholar, accessed October 10, 2019, https://scholar.google.com/scholar?hl=en\&as_sdt=0\%2C5\&q=Ko tler\%2C+Philip\%2C+and+Gary+Armstrong.+Fundamentos+de+Marketing.+Pearson+Educac $\mathrm{i} \% \mathrm{C} 3 \% \mathrm{~B} 3 \mathrm{n} \% 2 \mathrm{C}+2003 . \& \mathrm{btnG}=$.

${ }^{28}$ Adrian Sargeant, Marketing Management for Nonprofit Organizations (Oxford: Oxford University Press, 1999).

29 Adrian Sargeant, Marketing Management for Nonprofit Organizations (Oxford: Oxford University Press, 1999).

${ }^{30}$ Ryall Carroll and Luke Kachersky, "Service Fundraising and the Role of Perceived Donation Efficacy in Individual Charitable Giving," Journal of Business Research 99 (2019): 254-263. 
character of that? The aim is to provide a model to a develop a major gift model by adapting customer-oriented marketing theory, which could make donors receive more specific services with unique value.

Given the difficulty for large-gift donors to be studied through surveys or lab tests and our interest in studying the management model of major gifts for universities, we chose considered a qualitative case-study approach. ${ }^{31}$ The casestudy approach is particularly suitable for studying "how" research questions, and allowed us to explore the management structure of major gifts as well as to conduct an in-depth investigation of how universities conduct fundraising management. To be specific, using the snowball method to obtain additional interviews, ${ }^{32}$ we conducted interviews with 8 major gift donors and 15 university staff of fundraising management totally both in-person and through email. Although these people were asked the similar questions, respondents provided more detailed answers and we were able to ask follow-up questions. Some people were more willing to be interviewed if we had been directly referred by a colleague or partner. All the materials get in the interview which we use for this article is authorized by the interviewees. Apart from this, we also collected and analyzed the university's financial report, alumni association work report, and donation activities which could be found in public.

\section{The customer-oriented management structure of major gifts}

According to the customer orientation theory, it is necessary to establish a highly effective major gifts management structure and cross-departmental organizations in universities to adapt to the continuously changing educational donation market and donor demands. The organization structure of major gifts management in world-class U.S. universities has been continuously expanded and extended in practice, forming a major gifts management structure of "one body with multiple wings" (Figure 1). "One body" refers to the Office of Major Gifts, responsible for the major gifts management, coordination, and services for the entire university. "Multiple wings" refers to other coordinating offices related to major gifts management, working in conjunction to attract major gifts and to provide management services. This type of structure reflects two main characteristics of major gifts management in world-class U.S. universities. The first characteristic is the donation

${ }^{31}$ Robert K. Yin, Case Study Research: Design and Methods (Fourth Edition) (Thousand oaks: Sage, 2009).

${ }^{32}$ Norman K. Denzin and Yvonna S. Lincoln, The Qualitative Inquiry Reader (Thousand oaks: Sage, 2002). 
market subdivision and categorized management of donors. University major gifts mainly comprise of university alumni, non-alumni wealthy individuals, corporations, foundations, etc. Therefore, many universities have set up offices such as the Office of Enterprise Cooperation, Office of Foundation Cooperation, Office of Alumni Relationship, Presidents Club, and so on for categorized management and service of donors. These departments provide the Office of Major Gifts with prospective donor data and service support. The other characteristic is the functional subdivision of university donation management. To provide better donation management service, many universities have continuously optimized the donation management process through functional subdivision, and generally set up offices such as the Office of Fund-Raising Plan, Office of Fund-Raising Event, Office of Prospects Management, and so forth. In recent years, U.S. major gifts have started expanding internationally, with certain world-class universities, such as Harvard University, setting up an Office of Global Strategy to be responsible for planning the university's global development strategy. Meanwhile, universities also set the attraction of international major gifts as a main fund-raising strategy.

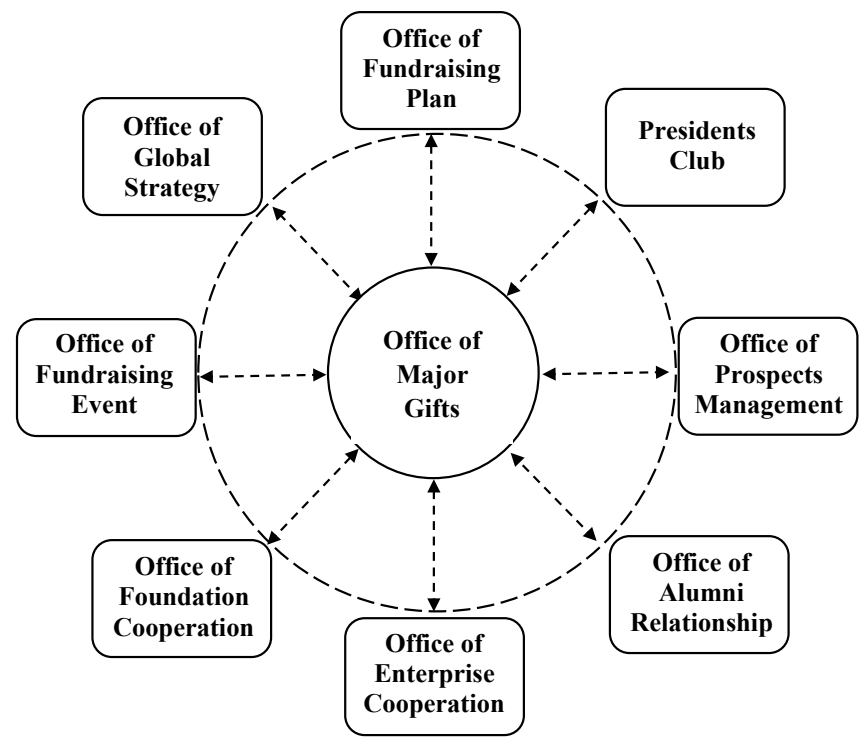

Figure 1

Organization structure of major gifts management in world-class U.S. universities 


\section{Analysis of customer-oriented nine-stage major gifts management model}

In the "customer-oriented" major gifts management model, the demands and value creation of major gifts donor are greatly emphasized. Major gifts donors are considered as important partners in fulfilling the university's missions and achieving outstanding performance as well as social capital for its development. The management model developed from the early three-stage theory "Identification - Cultivation - Solicitation" to the four-stage theory "Identification - Cultivation - Solicitation - Stewardship", and later to the fivestage theory "Identification - Qualification - Cultivation - Solicitation Stewardship". ${ }^{33}$ After reviewing a large number of articles and studying the case of the University of Pittsburgh, this article analyzes the model of major gifts management widely implemented in world-class U.S. universities, it is found that the current move management has a general and fuzzy analysis of the move, and the operability is not strong enough for some links are ignored. For example, definition is the beginning of a donation management activity and the database that could be used to identify prospect donors are different in universities. The University of Iowa use the ticket data from the university auditorium and then find many of those who frequently bought premium tickets also gave generously to fundraising efforts. ${ }^{34}$ Since most donors nowadays have its own unique motivation, if the fundraising staff don't prepare an appropriate fundraising project and communicating skills before making formal contact with potential donors, the effectiveness of subsequent contacts will be discounted. Through interviews and case study, we further refined the old model and develops a "nine-stage model" (Figure 2) consisting of "Definition - Identification - Qualification - Development of Strategy - Cultivation -Solicitation - Negotiation - Acknowledgment - Stewardship." But what deserves noting is that we should get the true spirit of move management rather than just think of it in a technical kind of way, which means "inspiring people to do the things that we believe they would want to do anyway, in other words, helping them accomplish what is consistent with their values and interests." 35

${ }_{33}$ Stanley Weinstein and Pamela Barden, The Complete Guide to Fundraising Management (Hoboken: John Wiley \& Sons, 2017).

34 "Data Analytics \& Development: 3 Ideas to Help Non-Profits Grow Gifts," last modified August 6, 2019, https://haianalytics.com/blog/data-analytics-development-3-ideasto-help-non-profits-grow-gifts.

35 “So I asked Dave Dunlop: Is 'moves management' misunderstood ?" Jim Lord, accessed October 2, 2019, https://leadershipphilanthropy.com/so-i-asked-dave-dunlop-ismoves-management-misunderstood/. 


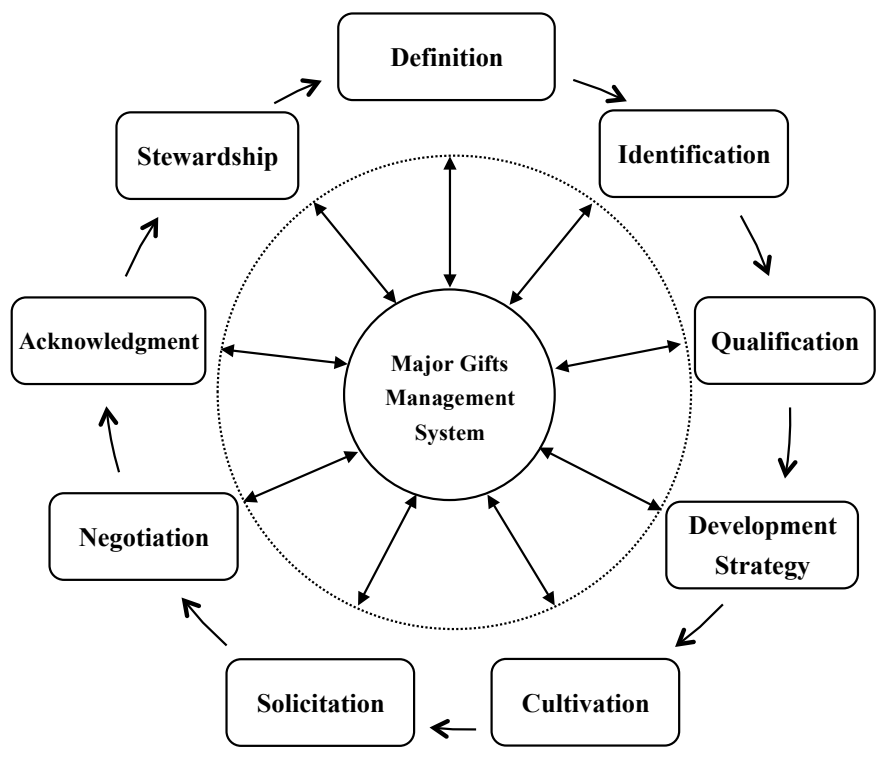

Figure 2

"Nine-stage model" implemented in world-class U.S major gifts management

\section{VI.1. Definition: Based on university strategy and fundraising target}

Study of major gifts management begins with a proper definition. For instance, how much counts as major gifts? Definition of major gifts varies in different universities. If the university's fundraising target is $\$ 1$ million, then $\$ 100,000$ would be a major gift; while if the target is $\$ 100$ million, $\$ 100,000$ would not be considered as a major gift. Generally speaking, in the fund-raising activities of world-class U.S. universities, higher overall strength and social reputation would imply a larger starting amount for major gifts. Definition differs as well based on donors' financial capacity. If the donor has $\$ 100$ million discretionary assets, then $\$ 100,000$ would not be a major gift, while $\$ 10,000$ would be if the donor only has $\$ 100,000$. Therefore, when universities are defining major gifts, multiple facets should be taken in consideration comprehensively: the number of university donors and their donation capability, the major gifts received over the past few years, as well the situation of competing universities of the similar category. Usually, universities use the "charting method" which subdivides the fundraising goal to define their major gifts. Generally, the top 10 donors contribute over $50 \%$ of the fundraising target, 
while the following 50 donors contribute $40 \%$, and the fundraising target can be reached by the top 150 donors ${ }^{36}$ Table 1 shows the number of donors and relevant donation amount with $\$ 10$ million as a university's fundraising target.

\section{Table 1}

Table of Gifts Required to Attain $\$ 10,000,000$

\begin{tabular}{|c|c|c|c|c|}
\hline No. of Gifts & Amount of Gift & Total this giving level & Cumulative total & Percent of goal \\
\hline 1 & $\$ 2,000,000$ & $\$ 2,000,000$ & $\$ 2,000,000$ & $20.00 \%$ \\
\hline 1 & $\$ 1,000,000$ & $\$ 1,000,000$ & $\$ 3,000,000$ & $30.00 \%$ \\
\hline 1 & $\$ 750,000$ & $\$ 750,000$ & $\$ 3,750,000$ & $37.50 \%$ \\
\hline 3 & $\$ 500,000$ & $\$ 1,500,000$ & $\$ 5,250,000$ & $52.50 \%$ \\
\hline 4 & $\$ 250,000$ & $\$ 1,000,000$ & $\$ 6,250,000$ & $62.50 \%$ \\
\hline \multicolumn{5}{|c|}{ Top ten gifts exceeding one-half of the goal } \\
\hline 8 & $\$ 100,000$ & $\$ 800,000$ & $\$ 7,050,000$ & $70.50 \%$ \\
\hline 12 & $\$ 75,000$ & $\$ 900,000$ & $\$ 7,950,000$ & $79.50 \%$ \\
\hline 15 & $\$ 50,000$ & $\$ 750,000$ & $\$ 8,700,000$ & $87.00 \%$ \\
\hline 15 & $\$ 25,000$ & $\$ 375,000$ & $\$ 9,075,000$ & $90.07 \%$ \\
\hline \multicolumn{5}{|c|}{ Next 50 gifts bringing the campaign to $90 \%$ of its goal } \\
\hline 25 & $\$ 15,000$ & $\$ 375,000$ & $\$ 9,450,000$ & $94.50 \%$ \\
\hline 35 & $\$ 10,000$ & $\$ 350,000$ & $\$ 9,800,000$ & $98.00 \%$ \\
\hline 40 & $\$ 5,000$ & $\$ 200,000$ & $\$ 10,000,000$ & $100.00 \%$ \\
\hline \multicolumn{5}{|c|}{ Campaign goal reached with more than 150 gifts } \\
\hline
\end{tabular}

Data Source: http://www.goettler.com/resources/the-goettler-series/volume-9-major-gifts/

VI.2. Identification: Finding prospective major gifts donors from the donor data pool

The main purpose of the identification stage is to screen for major gifts donors from the donor data pool. The donor data pool usually derives from

36 "Major Gifts Developing Strategies for Success." Goettler Associates, accessed June 12, 2014, http://www.goettler.com/resources/the-goettler-series/volume-9-major-gifts/. 

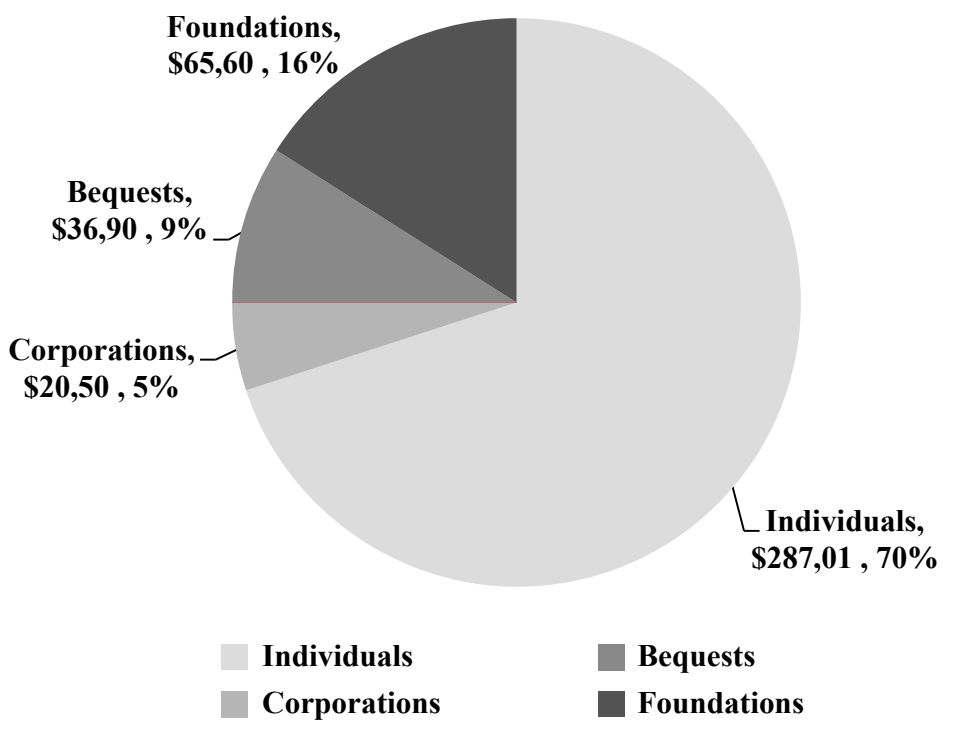

Figure 3

Source results from 2017 United States Philanthropy Report

the Office of Enterprise Cooperation, Office of Foundation Cooperation, Office of Alumni Relationship, Presidents Club, Office of Prospects Management, as well as the Forbes Philanthropy List, Richest List, technical reports on prospective major gifts donors, and other related data. Data from the 2017 United States Philanthropy Report showed (Figure 3) the four types of donation sources namely, wealthy individuals, corporations, foundations, and legacies. The total donation amount by wealthy individuals in 2014 was $\$ 287,010,000,000$, accounting for $70 \%$ of the total charitable income. This clearly shows that wealthy individuals make the vast majority of charitable contribution. Prospective major gifts donors can be discovered by establishing the "3C model" in order to filter and rank the data pool: ${ }^{37}$ (1) Capacity which mainly refers to the ability to donate manifested in the extent of financial support that the donor can provide. Often, potential donors with fixed assets above $\$ 10$ million and discretionary assets over $\$ 100,000$ are usually considered as having the financial capacity for major gifts; (2) Commitment which refers to the extent of donors' participation in charity events, their

37 "How do your prospects rank on the 3 C's?" Andrew Olsen, last modified March 7, 2012, http://andrewolsen.net/how-do-your-prospects-rank-on-the-3-cs/. 
major gifts donated to this organization or other similar organizations, the amount of past donations, and the differences of their donation amount to universities and other charity events; (3) Connection which mainly refers to the relationship between the university and donors, concerning whether the university has already established a relationship with donors, how strong the connection is, and so on. The Office of Major Gifts lists accordingly their TOP200, TOP100, TOP50, and TOP25, usually setting the TOP25 as the core major gifts donors to approach.

\section{VI.3. Qualification: Conducting research and confirming prospective major gifts donors}

The main task of the qualification stage is to conduct deeper research into chosen prospective major gifts donors to acquire related status data as well as to confirm their identity. Firstly, for better qualification of prospective major gifts donors, the Office of Major gifts usually establishes a four-to-sixmember qualification committee, consisting of the Chief Development Officer, Director of Office of Major Gifts, Major Gifts Officer, and others capable of attracting major gifts donors. ${ }^{38}$ The qualification committee is responsible for research and qualification of prospective major gifts donors and the establishment of their individual files. Research has shown that relying on donors' demographic information alone provides little insight into the incentive's donors give to nonprofits. ${ }^{39}$ More importantly, information for establishing effective communication with prospective major gifts donor should be included, for instance, current asset status and donation capability, educational background and employment history, social networks, including their membership in social groups and professional groups, the recent developments of commercial organizations under their names, the board of directors of their profitable and non-profitable organizations, their spouse's interests and hobbies, their past major gifts records, as well as their philanthropic philosophy, charitable tendencies and other information..$^{40,41}$

38 "Major Gifts Developing Strategies for Success." Goettler Associates, accessed June 12, 2014, http://www.goettler.com/resources/the-goettler-series/volume-9-major-gifts/.

39 Randy Stoecker, "Research Practices and Needs of Non-Profit Organizations in an Urban Center," J. Soc. \& Soc. Welfare 34 (2007): 97.

${ }^{40}$ Tanya Drollinger, "Using Active Empathetic Listening to Build Relationships with Major-Gift Donors," Journal of Nonprofit \& Public Sector Marketing 30, no. 1 (2018): 37-51.

${ }^{41}$ Breeze Beth, "The Coutts, Million Pound Donors Report 2011," (London: University of Kent,2011). 
After establishing the file, the qualification committee will normally categorize and rank prospective major gifts donors according to their charitable capacity, tendency, and maturity, followed by a more detailed qualification list of prospective major gifts donors.

\section{VI.4. Development Strategy: Formulating a relationship development strategy for prospective major gifts donors}

The main task of this stage is to formulate a focused relationship development strategy according to the characteristics of prospective major gifts donors and select compatible solicitation volunteers for them. ${ }^{42}$ University of Pittsburgh's Chief Development Officer emphasized that "university's development lays the foundation of the formulation of a development strategy; its nature is to market the university's ideals and mission, enabling major gifts management personnel to consider the university's development strategy on a higher level to cultivate potential major gifts donors into real major gifts donors and long-term cooperative partners. It not only has to do with the amount of money donated but also involves relationship development strategy for prospective major gifts donors, major gifts project planning and solicitation management strategy." ${ }^{43}$ Additionally, it is the key to successful solicitation to select compatible solicitation volunteers and fully support individualized development. Solicitation volunteers, possibly members of the board of directors or famous alumni, parents of students, or major gifts donors who have already established close relationships with the university, are usually selected based on their resources, capabilities and ability to establish effective relationships with prospective major gifts donors. In general, the development of strategy provides guidance for the conversion of potential major gifts donors into real major gifts donors, the core of which is selecting the right personnel, using the right method at the right time with the right project for the right prospective donor, and requesting for the right number of major gifts. Formulating the strategy development of prospective major gifts can effectively reduce solicitation time and increase the success rate.

${ }^{42}$ Virginia S. Harrison, "Understanding the Donor Experience: Applying Stewardship Theory to Higher Education Donors," Public Relations Review 44, no. 4 (2018): 533-548.

${ }^{43}$ Views raised in interviews, September 20, 2017. 


\section{VI.5. Cultivation: From linkage to involvement}

The main task of this stage is to progressively develop the relationship between the university and potential major gifts donors and their donation tendencies until the relationship and tendency mature to a level where solicitation is possible. ${ }^{44}$ The core of donor cultivation is finding shared values, continuously advocating the university's mission to the donor and involving them in it. ${ }^{45}$ Most potential major gifts donors can be categorized into different types. The first type refers to those who are already familiar with the university, recognizing the university's ideals, and having donated to the university in the past, such as members of the university's board of directors, advisory board members, distinguished alumni, and others involved with the university. The other type includes potential major gifts donors who are not familiar with the university, have yet to participate in the university's events and have no record of donations to the university. For the first type, it is often possible to solicit directly, with a strategy focusing on increasing their propensity for further donations. For the second type, a period of time is often needed for nurturing before solicitation, with 3-5 years or longer. Relationship nurturing has been defined as initiating and/or participating in dialogues with various public (including the use of social media) and expanding current involvement of individuals or public into long-term relationships through solicitations for donations and volunteer recruitment. ${ }^{46}$ For this type of donors, strategies are supposed to mainly focus on increasing mutual understanding and improvement of the relationship, for example, inviting potential donors of this type to participate in university activities or engage in informal communication to gradually gain their trust. A rush for quick result of solicitation won't work. ${ }^{47}$ As stated by a Professor of the University of Pittsburgh, donor cultivation generally goes through the following stages, "Prospect - Involver - Investor - Visionary" (Figure 4). ${ }^{48}$ The Director of the Office of Major Gifts from the University of Pittsburgh

${ }^{44}$ Kathleen S. Kelly, "Learning the ROPES: A New Theory Weaves Together the Many Strands of Fund-Raising Activity," CASE Currents 24, no. June (27-28) (1998): 30-31.

${ }^{45}$ Ken Burnett, Relationship Fundraising: A Donor-Based Approach to the Business of Raising Money (San Francisco: John Wiley \& Sons, 2002).

${ }^{46}$ Geah Nicole Pressgrove and Brooke Weberling McKeever, "Nonprofit Relationship Management: Extending the Organization-Public Relationship to Loyalty and Behaviors," Journal of Public Relations Research 28, no. 3-4 (2016): 193-211.

${ }^{47}$ Geah Pressgrove, "Development of a Scale to Measure Perceptions of Stewardship Strategies for Nonprofit Organizations," Journalism \& Mass Communication Quarterly 94, no. 1 (2017): 102-123.

48 Views raised in interviews, October 15, 2017. 
College of Education, pointed out that in reality, every possible participant in the decision-making for major gifts should be included in the scope of relationship cultivation, and should not be limited to the listed prospective major gifts donors. This would include the spouse, adult children, work partners, and financial and legal consultants of the prospective major gifts donors. $^{49}$

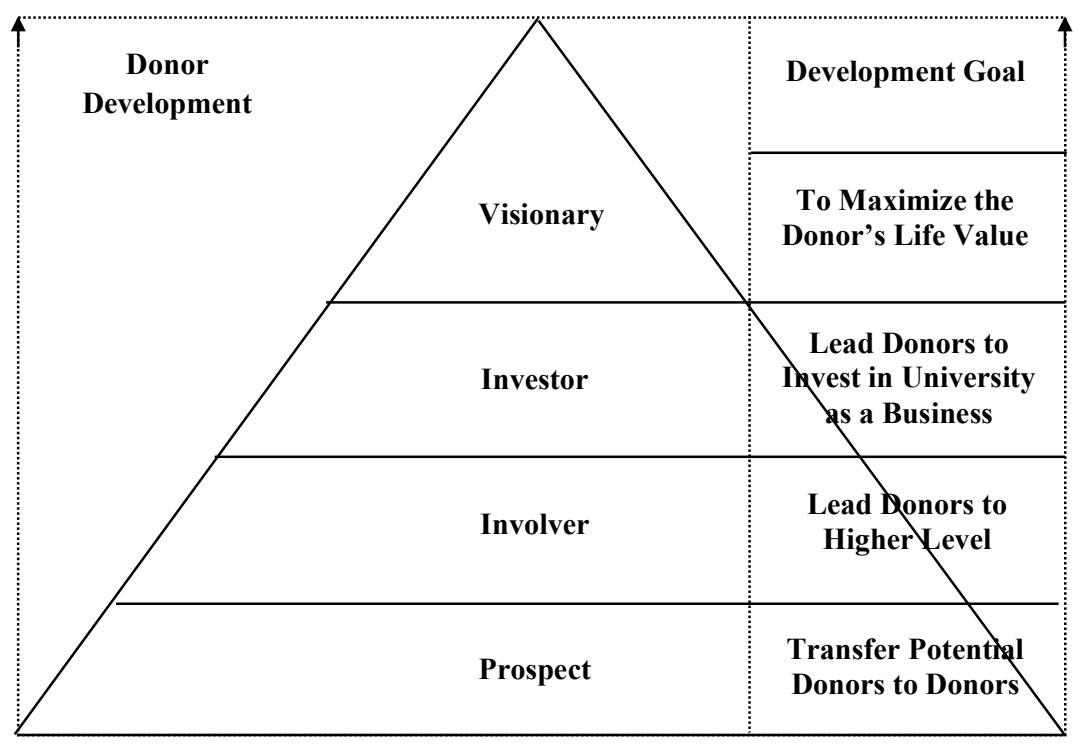

Figure 4

The development process of potential donors

Source: Organized by the author.

\section{VI.6. Solicitation: From involvement to investment}

The main task of this stage is to persuade the potential major gifts donors to donate through the effort of the solicitation team. Solicitation essentially converts potential donors from donors into investors. Solicitation usually follows the 5-W-principle: (1) Whom to solicit. Prioritizing the

${ }^{49}$ Views raised in interviews, September 20, 2017. 
major gifts donors with the greatest advocacy significance is very important as it would set a benchmark effect; (2) Who to send for solicitation. In the past, universities usually trained solicitation volunteers who began solicitation activities after selecting 3-5 names from the list of prospective major gifts donors, while currently the situation is reversed as "customer orientation" requires formulating a solicitation plan for each individual potential major gifts donor, followed by a focused selection of competitive solicitation volunteers to develop highly personalized solicitation activities; (3) When to solicit. The ideal time is when the relationship with prospective major gifts donor is matured enough for them to accept solicitation, and solicitation volunteers themselves have already donated generously; (4) What amount should be solicited. Solicitation amount mainly depends on the capability of the prospective major gifts' donors, relationship between the solicitation volunteers and the perspective major gifts donors, and the donors' understanding of the university mission as well as their desire to participate; (5) Why donate. In this stage, prospective donors are usually convinced by the university's statement on its mission, project, and customer value. The importance to fully grasp the motives and goals of donors for the initiative of volunteers has been proven before..$^{50,51}$ The key factors affecting the success of solicitation are friendly attitude of solicitation volunteers, feasible project plan and financial management mechanisms, acknowledgment plans based on donors' demand, as well as other evidence foreseeing successful fundraising. If solicitation fails, the process will return to the cultivation stage, unless donors have clearly stated the unwillingness to donate.

\section{VI.7. Negotiation: Embodiment of solicitation results}

The main task of this stage is to negotiate with donors or their representatives according to the consensus reached after successful solicitation to convert consultation to the finalized donation agreement. The negotiation group usually consists of solicitation volunteers, Director of the Office of Major Gifts, the Major Gifts Officer, etc. Evidence in major-donor giving also suggests that donors may consider to be part of the proposal

${ }^{50}$ Ken Burnett, Relationship Fundraising: A Donor-Based Approach to the Business of Raising Money (San Francisco: John Wiley \& Sons, 2002). 2012)

${ }^{51}$ Breeze Beth, The Million Pound Donors Report 2012 (London: University of Kent, 
creation as they prefer to donate in a unique and meaningful way. ${ }^{52,53}$ It takes one attempt or several rounds of consultation before an agreement is reached. The negotiation group needs ample patience and information to correctly understand the donor's wishes and demands, including donation payment method, beneficiary groups, areas of use, corresponding financial supervision, project operation plan, as well as the donor's special requests, which all require full and equal consultation with the donor. ${ }^{54}$ Donation usually take the form of cash, negotiable securities, real estate ownership, legacies, life insurance, charitable trust, material object, etc. In particular, consultation is needed to clarify the donation rewards and reputation incentives that will be provided for the donor. Strong emphasis should be placed on reward measures that match the donor's donation amount, philanthropic enthusiasm, matching of expected donation. For example, after donations reach a certain level, certain teaching venues or teaching facilities, and even a donation foundation can be named after the donor's name. "There are no right words for successful negotiation in one attempt, only correct questions and correct responses." ${ }^{55}$ Generally, the university is pleased to receive major gifts, but there are some donations that will put the university at risk, especially when the donor's donation source is unclear, the donor's demands go against the university's mission, or when it is harmful to the university's important interests; In face of such possible issues, the board of directors must consult again. Sometimes, the university needs to reject donation so as to maintain its independence or the sustainability of its mission and development strategy. ${ }^{56}$

\section{VI.8. Acknowledgment: Meeting the demands of donors}

The main purpose of this step is the timely acknowledgment of donors. It is an important step in major gifts management to accurately understand

${ }^{52}$ Ken Burnett, Relationship Fundraising: A Donor-Based Approach to the Business of Raising Money (San Francisco: John Wiley \& Sons, 2002).

${ }_{53}$ Breeze Beth, The Million Pound Donors Report 2012 (London: University of Kent, 2012).

54 “Donor Relations and Stewardship Defined,"Association of Donor Relations Professionals, accessed October 5, 2019, http://www.adrp.net/assets/documents/adrpdefinitionsexpanded.pdf.

${ }^{55}$ Eugene R. Tempel, Timothy L. Seiler, and Dwight F. Burlingame, Achieving Excellence in Fundraising (Hoboken: John Wiley \& Sons, 2016).

${ }_{56}$ Deni Elliott, The Kindness of Strangers: Philanthropy and Higher Education (Lanham: Rowman \& Littlefield Publishers, 2005). 
donor demands and appropriately express gratitude to donors, as it affects donor's donation experience and further donation possibility.$^{57}$ Generally speaking, the acknowledgment methods should suit the quantity, frequency, and effects of the donation received by the university. Not only does public recognition for donors' contributions matters, but also personal appreciation of donors from the recipient organizations. ${ }^{58}$ Currently, the means adopted for appreciation are the following:

1. Public acknowledgment: Donor's name and donation status shall be displayed on the university's main media, such as the university web portal, university newspaper, magazine, and local media, to publicize and commend the donor's generosity and contribution, spreading publicity to the donor's hometown, past employment locations, etc.

2. Denominate acknowledgment: The donor is supposed to be given the denominate rights to certain university buildings, venues, or teaching facilities when the donation reaches a certain quantity. When the donation is used to establish a long-term donation fund or scholarship, they shall also be given the naming rights.

3. Honorary acknowledgment: Special awards, such as "Distinguished Alumni," "Honorary Doctorate," "Honorary Professor," "Honorary Chairman," and so forth shall be presented to the donors if the monetary value of the donation is especially large to embody the donor's great contributions to the university.

4. Membership acknowledgment: Currently, many universities in the United States will grant club membership of different levels according to the donor's donation amount, enabling donors to enjoy different levels of membership service. Generally speaking, the larger the donors' donation amounts, the higher their club membership level. For example, in the University of Pittsburgh, its donor membership level is divided into the Common Rooms, Cornerstone, Lantern, Founders' Society and so on based upon the total donation amount of each fiscal year (Table 2).

57 Adrian Sargeant and Elaine Jay, Building Donor Loyalty: The Fundraiser's Guide to Increasing Lifetime Value (San Francisco: John Wiley \& Sons, 2004).

${ }^{58}$ Geah Pressgrove, "Development of a Scale to Measure Perceptions of Stewardship Strategies for Nonprofit Organizations," Journalism \& Mass Communication Quarterly 94, no. 1 (2017): 102-123. 
Table 2

Chancellor's Circle Donor Societies

\begin{tabular}{|l|c|}
\hline \multicolumn{1}{|c|}{ Level of donors } & Donation Amount (every fiscal year) \\
\hline Commons Room Society & $\$ 100,000$ and above \\
\hline Cornerstone Society & $\$ 50,000-\$ 99,999$ \\
\hline Lantern Society & $\$ 25,000-\$ 49,999$ \\
\hline John Bowman Society & $\$ 10,000-\$ 24,999$ \\
\hline Ruth Crawford Mitchell Society & $\$ 5,000-\$ 9,999$ \\
\hline George Woods Society & $\$ 2,500-\$ 4,999$ \\
\hline Founders' Society & $\$ 1,787-\$ 2,499$ \\
\hline William Jacob Holland Society & $\$ 1,000-\$ 1,786$ \\
\hline GOLD Circle (Young Alumni) & $\$ 500-\$ 999$ \\
\hline
\end{tabular}

Data Source: http://www.giveto.pitt.edu/node/369

\section{VI.9. Stewardship: New round of cultivation activities}

The main task of stewardship is to provide follow-up service and further development of donor relationships for the existing donation. ${ }^{59}$ Communication plays an important role, and more often than not, ineffective communication is the cause for relationship break-off, particularly with major donors who invested significantly ${ }^{60}$ On the one hand, stewardship should be performed according to the donation agreement; on the other hand, stewardship is a new round of relationship cultivation activity to maintain a good cooperative relationship between donors and the universities, which is vital to attaining further donations. ${ }^{61}$ Firstly, suitable commemorative and promotive activities should be designed according to donor's charitable demands. Taking the University of Pittsburgh as an example again, a

59 Adrian Sargeant and Stephen Lee, "Trust and Relationship Commitment in the United Kingdom Voluntary Sector: Determinants of Donor Behavior," Psychology \& Marketing 21, no. 8 (2004): 613-635.

${ }^{60}$ Katie McDonald, Wendy Scaife, and Susan Smyllie, "Give and Take in Major Gift Relationships,” Australian Journal of Social Issues 46, no. 2 (2011): 163-182.

${ }^{61}$ Kathleen S. Kelly, "Learning the ROPES: A New Theory Weaves Together the Many Strands of Fund-Raising Activity," CASE Currents 24, no. June (27-28) (1998): 30-31. 
donation induction ceremony is usually held after signing the donation agreement and the donor is invited to deliver a keynote speech, related stakeholders, university leadership, and media representatives all being invited. At the same time, the donor's deeds and importance of the donation project will be publicized through media. Furthermore, the performance effect and influence of the donation project shall be shared with the donor. In the past, regular reports were provided, while currently, with the widespread use of Twitter, Facebook and new social media, reports can be provided at any time and in various manifestations. If the donation project is a scholarship and grant, the donor shall be invited to join the scholarship selection committee, offering opinions on grants policy and selection. The university will also invite the donor to award and speak to the scholarship and grant beneficiary. If the donation project is donating buildings, facilities, or donation funds, apart from inviting the donor to attend related events, there is also a need to report to the donor on the equipment or status of fund use, informing the donor of how their donation is used. Furthermore, activities should be performed continuously according to the donor's society membership and related information shall be published frequently in order to guarantee his better understanding of the donation and the university. ${ }^{62}$ Finally, the donor information shall be updated in time to provide new data for the next round of donor identification.

\section{Discussion}

The wide application of customer-oriented major gifts management model facilitates the flourishing development of educational donation in world-class U.S. universities, contributing a lot to the development of U.S. tertiary education. The developmental characteristics are as follows.

\section{VII.1. An outside-inward thought orientation: From demand insight to value creation}

Customer-oriented major gifts management model emphasizes the importance of placing the donors in a center and focusing on the analysis and effects of donor demands. Thus, the university needs to understand the

${ }^{62}$ Virginia S. Harrison, "Understanding the Donor Experience: Applying Stewardship Theory to Higher Education Donors," Public Relations Review 44, no. 4 (2018): 533-548. 
donors' demands quickly and accurately, providing constant feedback and "expected objects" to donors, and constantly optimize self-management in accordance with changes in donor demands to improve "customer delivered value" as well as increase donor satisfaction and loyalty, which could possibly result in the donor's continued investment in the university. For charitable organizations, increasing donor loyalty by as little as $10 \%$ has been shown to raise the return rate on investment by $100 \%$ to $150 \% .{ }^{63}$ On the one hand, customer orientation model sets "external factors" such as donation demands as the starting point of major gifts management, emphasizing the dynamic mastering of donor demands through information analysis and relationship cultivation. In the information age, the development of social networking, new media, and information technology has facilitated to a great deal information research pertaining to major gifts. On the other hand, a university's "internal" efforts, such as improving major gifts management and continuously increasing "customer delivered value" should be accentuated. Universities need to closely follow donation market development and donor demand changes and strive to provide donors with a better donation experience and value perception by learning how to optimize the management process, increase university image and personnel quality, improve communication and interaction with donors, provide greater satisfaction commensurate with individualized demands for donation project and service, and maximize the reduction in donor's "customer total cost".

\section{VII.2. Relationship management of membership donors: Donor internalization and capitalization}

The deeper feature for the development of customer-oriented major gifts management is donors' internalization and capitalization. Donor "internalization" refers to viewing the donor as an important internal component of university development, thus providing management and relationship maintenance. To increase the loyalty of major gifts donor towards the university, many universities have constructed corresponding society membership levels according to the donation number of major gifts donors. Major gifts donor relationship can be continuously strengthened and their understanding of individual values and the university mission can be continually deepened through club events and services, thus converting

${ }_{63}$ Adrian Sargeant and Elaine Jay, Building Donor Loyalty: The Fundraiser's Guide to Increasing Lifetime Value (San Francisco: John Wiley \& Sons, 2004). 
a major gifts donor into a follower and executor of the university missions. Some influential major gifts donors will be absorbed into the university decision-making bodies, such as the board of directors, university development committee, university fundraising committee, alumni association, and other similar organizations, increasing their sense of belonging, honor, and mission. When donors are inspired by the life values and university mission and feel they are an important part of the university, they would often give their full support to a single university and provide a large amount of donation in a continuous manner. ${ }^{64}$ "Capitalization" is when the university views major gifts donors as an important asset of the university and a significant assessment criterion on the university's societal influence. This asset may grow continuously through investment. Hence personalized service shall be provided by and "total customer value" shall be increased so as to establish a close mutual relationship for further returns.

\section{VII.3. An inside-outward development of a strategy for cultivating prospective donors: Targets from national to international}

The cultivation of prospective donors lays the foundation for the development of university educational donations. Customer-oriented major gifts management model emphasizes inside-outward relationship cultivation with prospective donors, that is, focused relationship cultivation should be performed according to a descending order in terms of relationship strength. Local elites with strong relationship ties with the university, such as the university students and alumni are regarded as the focus of strategy development in relationship cultivation. Firstly, local elites enjoy a natural "short distance" and strong local ties with the universities, therefore having the highest possibility of being the target populations. Secondly, world-class U.S. universities view their students as strategic reserves of potential major gifts donors. On the one hand, universities strive to attract students to attending their institution events and to establish good relationships with these students, hoping that students will gain improvements and wonderful memories. Students are also more likely to give back after graduation

${ }^{64}$ Richard D. Waters and Denise Sevick Bortree, "Stewardship and involvement: Comparing the impact on nonprofit organizations' relationships with donors and volunteers,"in Annual conference of the Association for Education in Journalism and Mass Communication, Public relations division (Washington DC, 2013). 
because they feel they have received a benefit from their universities. ${ }^{65,66,67}$ On the other hand, universities also lay emphasis on the cultivation of charity awareness and charitable spirit among students, encouraging them to donate through student charity days and to donate their time to serve their alma mater and the community. Furthermore, distinguished alumni have always been a focus for university donations. Universities usually organize Homecoming festivities, project collaboration and other activities to develop closer relationships. Additionally, with the advancement of global higher education, Harvard, Yale, and other world-class U.S. universities have all began planning a global strategy, attempting to attract international major gifts-a trend that deserves attention.

\section{VII.4. Beyond "customer orientation": Moving towards integration of leading capacity building and donor orientation}

Customer-oriented major gifts management model is a product of the U.S. educational donation market and the marketing philosophy. Undeniably, customer orientation philosophy has a significant effect on assisting universities to follow market development, providing insight into donor demands, improving donation management, increasing donor satisfaction and loyalty. However, in the new economic era, with the development of educational donation market and rising donor awareness, major donors seek to exert a profound effect on the mission of the non-profits with their donation and to be involved in this process. ${ }^{68,69}$ Blindly pursuing "customer orientation" may cause universities to lose themselves in the donation market competition. As stated by the University of Pittsburgh Chief Development Officer, "Donor's high satisfaction does not secure high loyalty, and highly

${ }^{65}$ Xiaogeng Sun, Sharon C. Hoffman, and Marilyn L. Grady, "A Multivariate Causal Model of Alumni Giving: Implications for Alumni Fundraisers," International Journal of Educational Advancement 7, no. 4 (2007): 307-332.

${ }^{66}$ Julie O’Neil and Marisa Schenke, "An Examination of Factors Impacting Athlete Alumni Donations to Their Alma Mater: A Case Study of a US University," International Journal of Nonprofit and Voluntary Sector Marketing 12, no. 1 (2007): 59-74.

${ }^{67}$ Kelly A. Marr, Charles H. Mullin, and John J. Siegfried, "Undergraduate Financial Aid and Subsequent Alumni Giving Behavior," The Quarterly Review of Economics and Finance 45, no. 1 (2005): 123-143.

${ }^{68}$ Ken Burnett, Relationship Fundraising: A Donor-Based Approach to the Business of Raising Money (San Francisco: John Wiley \& Sons, 2002).

${ }^{69}$ Paul G. Schervish, "Major Donors, Major Motives: The People and Purposes behind Major Gifts," New Directions for Philanthropic Fundraising 2005, no. 47 (2005): 59-87. 
satisfied donors may offer their donations to other universities that provide them with unique values." 70 Therefore, if a university wants to secure an advantage in the competitive market, simply following the idea of donor orientation is not enough. The question of how to design new donation projects and services for donors, and of how to create unique values has become a key subject for university major gifts management. Apart from customer orientation, they are also supposed to focus on creating leading capabilities and donation demands and constantly provide new values for donors, initiating new charity philosophies, leading donors into unknown territories. On the one hand, universities need to establish a leading edge by raising education quality and developing outstanding fields and school characteristics; on the other hand, universities still need to strengthen their pro-activeness and attract the continuous investment from more donors through their mission by launching research tackling social difficulties and hot topics of future society.

In summary, good donation management serves as the prerequisite for better donations, especially at the current stage for China where modernization of higher education donation has just begun. The philosophy, mechanisms and methods, as well as professional organization and team building still need further research and investigation, where the US experiences can provide us with an excellent reference.

\section{VII.5. Limitations and future research}

This paper makes an in-depth analysis of major gifts model of top universities in the United States, summarizes the characteristics and development trends of its management model, and puts forward suggestions for universities about major gifts management. And future studies might be deployed in several directions.

First of all, it is necessary to do a comparative analysis on the management model of major gifts universities in different countries. Given the differences in the socio-economic conditions of different countries and the various cultural atmosphere of university donations, the pattern of major gifts may also vary. Comparison and analysis of the major gifts models of countries at different stages of development is not presented due to the limited space in this paper. Future studies about the rules of various types of large-scale donations and the differences between different types of major gifts could be invited.

${ }^{70}$ Views raised in interviews, September 22, 2017. 
Next, the issue of major gifts and higher education equity is worth investigating. On the one hand, the fundraising movement has the "Matthew effect", which means the more elite positions, higher social prestige, stronger academic strength and longer history a university possesses, the easier it is to launch billions of dollars fundraising campaigns and receive huge donations. Local universities with poorer schooling quality have relatively fewer investments in obtaining fundraising, which renders them fall short of elite universities in terms of the goal, strategy and scale of fund-raising campaign. Therefore, their funding for running schools is relatively limited. On the other hand, the original balance of higher education will be broken when market forces excessively "invade" higher education. As a result, the strategic choice of educational decision-makers is more often than not utilitarian, rather than being long-term-oriented, hence the unbalanced and unreasonable allocation of educational resources. Therefore, the value of studying this issue of major gifts and the fairness of higher education cannot be emphasized enough.

Third, the relationship between large gifts and government responsibility needs study as well. Higher education has a nature of being a quasi-public product, and the government bears the responsibility for its development. Studies have shown that there is a trade-off between government higher education grants and higher education donations. The rise of the total amount of higher education donations renders the government to believe that higher education funds are sufficient, thus reducing financial allocations, and vice versa. According to the statistics of the Voluntary Support Education (VSE) of the American Education Aid Commission, in recent years, the investment in higher education in the social charity field has increased year by year, and its proportion of the university's fiscal revenue has also increased year by year. However, the proportion of government financial allocation to university financial revenue is declining as time progresses. The challenge faced by the government and decision makers in higher education is how to maintain development of higher education institutions while abiding by market rules, and how to deal with the conflict between market interests and the sacred responsibilities of higher education institutions. What matters is to adjust the relationship between supply and demand, and truly mobilize public and private resources to better promote the development of higher education and better meet the needs of social development and national development.

Fourth, globalization of donations and international competition should not be ignored. The quality certification system for higher education marked by the global university ranking is increasingly taking shape. Various 
countries have internationalized, globalized, and entrepreneurialized higher education, and taken the output of higher education as a national strategy. Therefore, university fundraising must break through national borders and go global, striving for more resources for running education in global competition and enhance the university's influence. At the university level, global competition for fundraising campaigns will increasingly test the global vision, strategic vision and execution of university fundraising leaders, as emphasized by assistant vice president of the University of George Washington and director of the fundraising campaign office: "where is the wealth of the world, and where are we going? If we don't go, our alumni may soon become donors to other universities". ${ }^{71}$ With the further advancement of higher education globalization, overseas markets will become an important growth point for university fundraising, which means more intense global competition will emerge. How to adapt to the fundraising competition in the era of fundraising globalization will be an important and pressing new topic.

Finally, the challenge of major gifts in the Internet age deserves special attention. With the advent of the Internet era and the further development of convenient payment tools, new demands are put forward for the donation management. In addition to paying attention to the traditional fundraising management, it is prominent to capitalize on social media to maximize the impact and coverage of donation projects, enhance the personalization of donation projects, make analysis and decisions on big data, and maintain online relationships with donors. In addition, the new characteristics of donors from the young generation who grow up in the Internet era are expected to be catered to. Therefore, a future study that goes deeper into the emerging donation management model in the Internet age is promising.

\section{Bibliography}

Association of Donor Relations Professionals. "Donor Relations and Stewardship Defined." Accessed October 5, 2019.

Avectra."The New Model of Moves ManagementForEffective Fundraising."Accessed October 5, 2019. http://cdn2.hubspot.net/hub/447141/file-2184258567-pdf/ The-New-Model-Of-Moves-Management-For-Effective-Fundraising Avectra.pdf?t=1417809451029. https://www .adrp.net/assets/documents/ adrpdefinitionsexpanded.pdf.

${ }^{71}$ Views raised in interviews, September 28, 2017. 
Bandura, Albert. "The Explanatory and Predictive Scope of Self-Efficacy Theory." Journal of Social and Clinical Psychology 4, no. 3 (1986): 359-373.

Bekkers, René, and Pamala Wiepking. "A Literature Review of Empirical Studies of Philanthropy: Eight Mechanisms That Drive Charitable Giving." Nonprofit and Voluntary Sector Quarterly 40, no. 5 (2011): 924-973.

Beth, Breeze. The Coutts, Million Pound Donors Report 2011. London: University of Kent, 2011.

- The Million Pound Donors Report 2012. London: University of Kent, 2012.

Burnett, Ken. Relationship Fundraising: A Donor-Based Approach to the Business of Raising Money. San Francisco: John Wiley \& Sons, 2002.

Carroll, Ryall, and Luke Kachersky. "Service Fundraising and the Role of Perceived Donation Efficacy in Individual Charitable Giving." Journal of Business Research 99 (2019): 254-263.

Denzin, Norman K., and Yvonna S. Lincoln. The Qualitative Inquiry Reader. Sage, 2002.

Drollinger, Tanya. "Using Active Empathetic Listening to Build Relationships with Major-Gift Donors.” Journal of Nonprofit \& Public Sector Marketing 30, no. 1 (2018): 37-51.

Duronio, Margaret A., and Bruce A. Loessin. Effective Fund Raising in Higher Education: Ten Success Stories. ERIC, 1991.

Elliott, Deni. The Kindness of Strangers: Philanthropy and Higher Education. Rowman \& Littlefield Publishers, 2005.

Erie, Thomas. Mary K. Blair. Hughes-Hallett, and P. Lampl. Increasing Voluntary Giving to Higher Education: Task Force Report to Government. Nottingham: Department for Education and Skills, 2004.

European Fundraising Association. "Special Focus: What today's philanthropists really want." Last modified September 18, 2019. https:/efa-net.eu/features/ special-focus-what-todays-philanthropists-really-want.

Fajardo, Tatiana M., Claudia Townsend, and Willy Bolander. "Toward an Optimal Donation Solicitation: Evidence from the Field of the Differential Influence of Donor-Related and Organization-Related Information on Donation Choice and Amount." Journal of Marketing 82, no. 2 (2018): 142-152.

Funds101. "Fundraising Cycle." Last modified January 30, 2013. http://funds101. blogspot.com/2013/01/fundraising-cycle.html.

Gailperry Association. "Major Gifts Series \#8: How to Use Moves Management To Raise Major Gifts This Year." https://www.gailperry.com/how-to-use-movesmanagement-to-raise-major-gifts/.

Goettler Associates. "Major Gifts Developing Strategies for Success." Accessed June 12, 2014. http://www.goettler.com/resources/the-goettler-series/volume-9major-gifts/.

Haddad, Duke. "Donor Cultivation Is Key to Success.” Last modified June 29, 2018. https://www.nonprofitpro.com/post/donor-cultivation-is-key-to-success/ 
HAI Analytics. "Data Analytics \& Development: 3 Ideas to Help Non-Profits Grow Gifts." Last modified August 6, 2019. https://haianalytics.com/blog/dataanalytics-development-3-ideas-to-help-non-profits-grow-gifts.

Harrison, Virginia S. "Understanding the Donor Experience: Applying Stewardship Theory to Higher Education Donors." Public Relations Review 44, no. 4 (2018): 533-548.

He, Yurong. "A literature review of higher education donation system in China." China Electric Power Education. no. 28(2011): 19-21.

Jones, Jennifer A., and David L. Daniel. "Academic and Practitioner Collaborations in Fundraising Research: A Case Study of One Action Research-Driven Collaboration." The Journal of Nonprofit Education and Leadership 9, no. 2 (2019).

Kelly, Kathleen S. "Learning the ROPES: A New Theory Weaves Together the Many Strands of Fund-Raising Activity." CASE Currents 24, no. June (27-28) (1998): 30-31.

- Effective Fund-Raising Management. Mahwah: Routledge, 1998.

, and Chuck Kelly. Fund Raising and Public Relations: A Critical Analysis. Lawrence Erlbaum Associates, 1991.

Kotler, Philip, and Gary Armstrong. Fundamentos de Marketing. Google Scholar. accessed October 10, 2019. https://scholar.google.com/scholar?hl=en\&as sdt=0 $\% 2 \mathrm{C} 5 \& \mathrm{q}=\mathrm{Kotler} \% 2 \mathrm{C}+$ Philip $\% 2 \mathrm{C}+$ and+Gary+Armstrong.+Fundamentos+de+ Marketing.+Pearson+Educaci\%C3\%B3n\%2C+2003.\&btnG=.

Levitt, Theodore. Marketing Myopia. London: Boston, 1960.

Lord, Jim. "So I asked Dave Dunlop: Is 'moves management' misunderstood?" Accessed October 2, 2019. https://leadershipphilanthropy.com/so-i-asked-davedunlop-is-moves-management-misunderstood/.

Marr, Kelly A., Charles H. Mullin, and John J. Siegfried. "Undergraduate Financial Aid and Subsequent Alumni Giving Behavior." The Quarterly Review of Economics and Finance 45, no. 1 (2005): 123-143.

McDonald, Katie, Wendy Scaife, and Susan Smyllie. "Give and Take in Major Gift Relationships.” Australian Journal of Social Issues 46, no. 2 (2011): 163-182.

Meng, Yan, and Hong Chengwen. "Strategies and implications of fund-raising campaign at the University of Toronto." Chongqing higher education research. no.5 (2017): 92-100.

Narver, John C., and Stanley F. Slater. "The Effect of a Market Orientation on Business Profitability." Journal of Marketing 54, no. 4 (1990): 20-35.

O’Neil, Julie, and Marisa Schenke. "An Examination of Factors Impacting Athlete Alumni Donations to Their Alma Mater: A Case Study of a US University." International Journal of Nonprofit and Voluntary Sector Marketing 12, no. 1 (2007): 59-74.

Olsen, Andrew. "How do your prospects rank on the 3 C's ?" Last modified March 7, 2012. http://andrewolsen.net/how-do-your-prospects-rank-on-the-3-cs/.

People. "Record! Bloomberg announced a donation of $\$ 1.8$ billion to his alma mater [Chinese]." Last modified November 19,2018. http://ah.people.com.cn/ n2/2018/1119/c358315-32305418.html. 
. "Tsinghua won the highest donation amongst domestic universities for 2.2 billion-yuan [Chinese]." Last modified October 23, 2018. http://edu.people.com. $\mathrm{cn} / \mathrm{n} 1 / 2018 / 1023 / \mathrm{c} 1053-30357207 . \mathrm{html}$.

Pressgrove, Geah Nicole, and Brooke Weberling McKeever. "Nonprofit Relationship Management: Extending the Organization-Public Relationship to Loyalty and Behaviors." Journal of Public Relations Research 28, no. 3-4 (2016): 193-211. Pressgrove, Geah. "Development of a Scale to Measure Perceptions of Stewardship Strategies for Nonprofit Organizations." Journalism \& Mass Communication Quarterly 94, no. 1 (2017): 102-123.

Rogers, Ronald W. "A Protection Motivation Theory of Fear Appeals and Attitude Change1." The Journal of Psychology 91, no. 1 (1975): 93-114.

Rosen, Michael J.Donor-Centered Planned Gift Marketing:(AFP Fund Development Series). Vol. 192. John Wiley \& Sons, 2010.

Sargeant, Adrian, and Elaine Jay. Building Donor Loyalty: The Fundraiser's Guide to Increasing Lifetime Value. San Francisco: John Wiley \& Sons, 2004.

Sargeant, Adrian, and Stephen Lee. "Trust and Relationship Commitment in the United Kingdom Voluntary Sector: Determinants of Donor Behavior." Psychology \& Marketing 21, no. 8 (2004): 613-635.

Sargeant, Adrian. Marketing Management for Nonprofit Organizations. Oxford: Oxford University Press Oxford, 1999.

Schervish, Paul G. "Major Donors, Major Motives: The People and Purposes behind Major Gifts." New Directions for Philanthropic Fundraising 2005, no. 47 (2005): 59-87.

Stoecker, Randy. "Research Practices and Needs of Non-Profit Organizations in an Urban Center." J. Soc. \& Soc. Welfare 34 (2007): 97.

Sun, Xiaogeng, Sharon C. Hoffman, and Marilyn L. Grady. "A Multivariate Causal Model of Alumni Giving: Implications for Alumni Fundraisers.” International Journal of Educational Advancement 7, no. 4 (2007): 307-332.

Tang, Wei. School management strategy: university budget allocation, fundraising and marketing. Taiwan: Wunan Book Publishing Co., Ltd, 2001.

Tempel, Eugene R., Timothy L. Seiler, and Dwight F. Burlingame. Achieving Excellence in Fundraising. Hoboken: John Wiley \& Sons, 2016.

Waters, Richard D., and Denise Sevick Bortree. "Stewardship and involvement: Comparing the impact on nonprofit organizations' relationships with donors and volunteers."Annual conference of the Association for Education in Journalism and Mass Communication, Public relations division. Washington DC, 2013.

Weinstein, Stanley, and Pamela Barden. The Complete Guide to Fundraising Management. Hoboken: John Wiley \& Sons, 2017.

Worth, Michael J. New Strategies for Educational Fund Raising. Westport: Rowman \& Littlefield Publishers, 2002.

Yin, Robert K. Case Study Research: Design and Methods (Fourth Edition). Thousand oaks: Sage, 2009. 


\section{About the authors}

CHENGHUA LIN (chlin@zju.edu.cn) is Associate Professor, Doctoral Supervisor, and Deputy Director of Institute of Technology Innovation and Management, Research Institute of China's Science, Technology and Education Policy, School of Public Affairs, Zhejiang University, China. His research area is university fundraising and endowment investment, higher education development strategy, and science and technology innovation management. He has participated in the design of the 120-year grand fundraising project of Zhejiang University and the five-year fundraising strategic action plan. He also participated in the fundraising action plan of the new campus of Lake University and the global fundraising project planning of Yuelu Academy of Hunan University in China.

YANJIE XIE (xieyanjie94@163.com) is a PhD student in School of Public Affairs in Zhejiang University, China. Her research interests focus on innovation and entrepreneurship in higher education and higher education development strategy.

RUIXUE XU (954015186@qq.com) is a Master's student in School of Public Affairs in Zhejiang University, China. Her research interests focus on higher education development strategy. 


\title{
Experience and enlightenment: "Customer-oriented" nine-stage major gifts management model of world-class U.S. universities
}

\author{
Chenghua Lin, Yanjie Xie, and Ruixue Xu
}

doi: http://dx.doi.org/10.18543/tjhe-7(1)-2019pp33-65

\section{Copyright}

Copyright for this article is retained by the Publisher. It is an Open Access material that is free for full online access, download, storage, distribution, and or reuse in any medium only for noncommercial purposes and in compliance with any applicable copyright legislation, without prior permission from the Publisher or the author(s). In any case, proper acknowledgement of the original publication source must be made and any changes to the original work must be indicated clearly and in a manner that does not suggest the author's and or Publisher's endorsement whatsoever. Any other use of its content in any medium or format, now known or developed in the future, requires prior written permission of the copyright holder. 